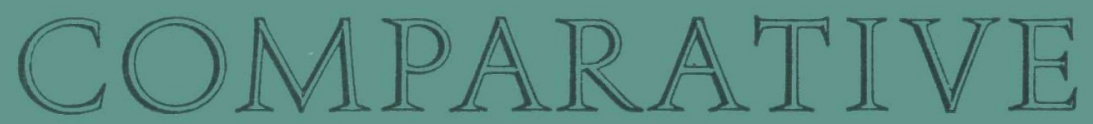

STUDIES IN

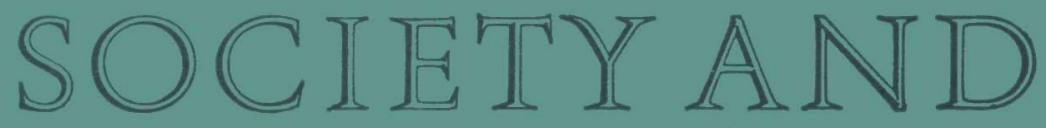

HISTORY

AN INTERNATIONAL QUARTERLY

\author{
VOLUME 22 NUMBER 2 \\ APRIL \\ 1980
}

CAMBRIDGE UNIVERSITY PRESS 
RAYMOND GREW ERIC R. WOLF
History

Anthropology
University of Michigan

Herbert H. Lehmann College, CUNY
SyLVIA L. THRUPP ARAM A. YENGOYAN
BOOKREVIEW EDITORS
History
Anthropology
University of Michigan
University of Michigan

EDITOR I A L COM M T T EE

$\begin{array}{lll}\text { ALBERT FEUERWERKER } & \text { East Asian History } & \text { University of Michigan } \\ \text { SIR MOSES FINLEY } & \text { Ancient History } & \text { University of Cambridge } \\ \text { CHARLES GIBSON } & \text { Latin American History } & \text { University of Michigan } \\ \text { JACOB M. PRICE } & \text { Economic History } & \text { University of Michigan } \\ \text { GAVIN WRIGHT } & \text { Economics } & \text { University of Michigan }\end{array}$

Bernard S. Cohn NaTalie Z. Davis S. N. EISENSTADT ClifFord GEERT $Z$

\section{JACK GOODY}

OLEG GRABAR

DaVID GuTMANN

DAVID HERLIHY

JOHN HIGHAM

GEORGE KUBLER

GERHARD LENSKI

Claude Levi-Strauss

EMmanuel Le Roy

LADURIE

JUAN LINZ

HaNS MEdick

Alfred G. Meyer

STEIN ROKKAN

NeIL SMeLser

Charles Tilly

\section{CONSULTING EDITOR S}

Anthropology and History
History
Sociology
Anthropology

Anthropology
Islamic Art
Psychology
History
American History
Art History
Sociology
Anthropology
History
Sociology
History
Political Science
Comparative Politics
Sociology

Sociology and History

\author{
University of Chicago \\ Princeton University \\ Hebrew University, Jerusalem \\ Institute for Advanced \\ Study, Princeton \\ University of Cambridge \\ Harvard University \\ Northwestern University \\ Harvard University \\ Johns Hopkins University \\ Yale University \\ University of North Carolina \\ Collège de France \\ Collège de France \\ Yale University \\ Max-Planck Institut für \\ Geschichte, Göttingen \\ University of Michigan \\ University of Bergen \\ University of California, \\ Berkeley \\ University of Michigan
}

\section{S U B S C R I P T IO N S}

Comparative Studies in Society and History (ISSN 0010-4175) is published quarterly in January, April, July and October. The subscription price of Volume 22, 1980, is £21.00 (US $\$ 49.50$ in the U.S.A. and Canada) for institutions, postage included. Individuals ordering direct from Cambridge University Press and certifying that the journal is for their personal use may subscribe at a reduced rate of $£ 11.50$ (US $\$ 25.00$ in the U.S.A. and Canada). Single issues are sold for $£ 6.00$ (US $\$ 15.00$ ) plus postage. Orders, which must be accompanied by payment, should be sent to a bookseller or subscription agent or direct to Cambridge University Press, P.O. Box, 110, Cambridge CB2 3RL, and in the U.S.A. and Canada, to Cambridge University Press, 32 East 57th Street, New York, N.Y. 10022 . Second class postage paid in New York, N.Y. POSTMASTER: send address changes in U.S.A. and Canada to Cambridge University Press, 32 East 57th Street, New York, N.Y. 10022.

\section{Copying}

This journal is registered with the Copyright Clearance Center, P.O. Box 8891, Boston, Mass. 02114. Organizations in the U.S.A. who are also registered with C.C.C. may therefore copy material (beyond the limits permitted by sections 107 and 108 of U.S. copyright law) subiect to payment to C.C.C. of the per-copy fee indicated in the code on the first page of the article. This consent does not extend to multiple copying for promotional or commercial purposes.

ISI Tear Service, 3501 Market Street, Philadelphia, Pennsylvania 19104, U.S.A. is authorized to supply single copies of separate articles for private use only.

For all other use, permission should be sought from the Cambridge or New York offices of the Cambridge University Press. 